\title{
The Novel Glycoprotein Structure; $C$-Mannosyl Tryptophan
}

\author{
タンパク質修飾の新しい形；C-結合型糖ペプチド
}

\author{
Manabe, Shino ;and Ito, Yukishige \\ RIKEN (The Institute of Physical and Chemical Research), Hirosawa, Wako-shi, Saitama 351-0198, Japan \\ FAX: 81-48-462-4680, E-mail: smanabe@ postman.riken.go.jp
}

Key Words: C-mannosylated tryptophan, glycoprotein, glycopeptide, total synthesis

\begin{abstract}
Glycosylation is one of the most important post- or cotranslational modifications of proteins, which affects the biological activities of the parent proteins by influencing the higherorder structure. This modification has been classified into two subtypes: namely $N$-linked type and $O$-linked type. Recently, a highly novel variant of glycoproteins that incorporate a $C$ glycosylated amino acid was identified in various proteins. The total synthesis of one such $C$-glycosyl amino acid, namely, $C^{2}$ $\alpha$-D-C-mannosylpyranosyl-L-tryptophan and related peptides was successfully achieved. The mannose and tryptophan moieties were connected via a ring opening of benzyl-protected 1,2anhydro-mannose by a lithiated indole derivative. After the functional group conversion and deprotection steps, the glyco-amino acid was synthesized in a concise and stereoselective manner, in high overall yields. Furthermore, intermediate azide acid can serve as a useful building block for peptide elongation. The stereoisomer, $C^{2}-\alpha$-D- $C$-glucosylpyranosyl-L-tryptophan was synthesized in a similar way.

We describe here the synthesis of $C$-Man-Trp including by other groups and the possibility of application to clinical methods.
\end{abstract}

要 約

糖鎖修飾はタンパク質の翻訳後修飾のもっとも大切なかた ちのひとつであり、タンパク質の高次構造を変化させることに より活性を調節する。タンパク質糖鎖修飾は $N$-結合型と $O$-結合 型に分類されてきた。しかしながら最近、新規タンパク質修飾 型としてさまざまなタンパク質に $C$-結合型糖鎖が見出されてい る。新規に見出された $C$-マンノシルトリプトファンの合成に成 功した。マンノースとトリプトファンはベンジル基で保護した 1,2-アンヒドロマンノースとリチオ化したインドールとの反応に より、結合させた。官能基変換と脱保護反応を経て $C$-マンノシ ルトリプトファンを短工程、高収率で合成できた。また、その 構造を含むぺプチドや立体異性体の合成にも成功している。 我々の合成を中心に他のグループによる合成、臨床への応用の 可能性について述べる。

\section{A. はじめに}

生体内で機能するタンパク質はDNA に貯えられている遺 伝情報をもとに合成されるが、翻訳後すぐに機能を発揮するこ とはまれであり、ジスルフィド結合の形成、リン酸化、ユビキ チン化などの翻訳後修飾を受けて成熟した形として発現し、そ の機能を発揮するものも多い(1)。グリコシル化反応はそのよう な翻訳後修飾の典型的なかたちのひとつであるが、他の修飾型 に比べてかさ高いことからタンパク質のコンフォメーションを 変えたり、ペプチダーゼからの安定性を向上させたりする働き も持つ $(2 、 3)$ 。タンパク質を修飾する糖鎖の形としてはおおおま 
involved in the binding process of molecular recognition systems in the form of glycoproteins.

Although other linkages have been reported, in most cases, protein glycosylation can be classified into two major groups: i) $\mathrm{O}$-glycosylation, where an $\mathrm{N}$-acetylgalactosamine residue is covalently attached to the hydroxyl group of either serine or threonine of the protein, and ii) $\mathrm{N}$-glycosylation, where a glycan chain is linked via a glycosylamido linkage to an asparagine side chain $(4,5)$. The latter is further classified into subtypes as high mannose-type, complex-type, and hybrid-type.

However, in 1994, a novel class of glycoprotein structural type (Figure 1) was identified in human RNase Us, where a mannose residue is connected to tryptophan via a $C$-glycosidic linkage (6-9). The primary structure of glycosylated peptide 2 was determined by Edman degradation, and by mass and NMR spectroscopy. Peptides from different enzymatic digests, which contained Trp-7, were found ESI-MS to have a mass, which is a $162 \mathrm{Da}$ higher than expected for a non-modified peptide. In addition, the loss of $120 \mathrm{Da}$, which is a characteristic feature of low molecular weight $C$-glycopyranoside. ${ }^{1} \mathrm{H}-\mathrm{NMR}$ analysis revealed that all protons of the indole side chain were observed, except for the one at position 2.

Now, it is possible to determine the $C$-mannnosylated tryptophan from Edman degradation. Although phenylthiohydantoinMan-Trp was initially reported that the major derivative eluted shortly after Phenythiohydantoin-Tyr, further experiment revealed that in most of the time, it was co-eluted. This problem could be solved by adequate choice of buffer composition and batches of column material (10). Another problems are the low yield and reproducibility of phenylthiohydantoin-Man-Trp during Edman degradation.

Although the function of $C$-glycosylated tryptophan is still unclear, additional examples of $C$-mannosylated proteins are continually discovered from several sources, including recombinant human IL-12 expressed in Chinese hamster ovary cells(11), thrombospondin type 1 repeat $(12,13)$, and terminal components of complement (C6, C7, C8 and C9)(14). Most strikingly, properdin (15), a positive regulator of complement, contains 20 tryptophan residues, in which as many as 17 are
には $N$-結合型糖鎖と $O$-結合型糖鎖の 2 つにわけられてきた。 $N$-結合型糖鎖はアスパラギン側鎖アミド基を介して糖鎖とタン パク質が結合しており、O-結合型では糖鎖とタンパク質が側鎖 水酸基を介して結合している。 $N$-結合型糖鎖はさらに high-mannose タイプ、complex タイプ、hybrid タイプにわけられ、また $O$-結合型糖鎖は Core 1 から Core 8 まで類別される $(4 、 5)$ 。

しかしながら 1994 年、Hofsteenge らによりマンノースアノ マー位とトリプトファンが炭素結合を介して結合した新規修飾 型がヒトRNase より発見された(6-9)(Figure 1)。これは RNase を Edman 分解した後のへキサペプチドを NMR とMSにより分 析した結果明らかになったものである。ESI-MS では RNaseの Trp-7 において $162 \mathrm{Da}$ の分子量の増加が観測された。さらに C-グリコシドで特徵的にあらわれるマススペクトルでの $120 \mathrm{Da}$ のフラグメンテーションが観測されることよりO-グリコシドで はなくC-グリコシドであると推測された。NMR においてイン ドールの 2 位の水素以外はすべて観測できることからトリプト ファンのインドール 2 位でマンノースと結合していると推測さ れた。

現在では Edman 分解によりC-マンノシル化されたトリプ トファンの存在を知ることもできる。一般的な条件では phenylthiohydantoin-(C2-Man-Trp) と phenylthiohydantoin-Tyr の 分離は難しいが、ある緩衝液条件下、またはカラムの担体を選 択すると phenylthiohydantoin-(C2-Man-Trp) は phenylthiohydantoinTyr のすぐ後に溶出される (10)。またマンノシル化されたトリ プトファンの phenylthiohydantoin への収率は他のアミノ酸に比 べて若干低く、再現性が十分でないこともこの修飾型を発見し にくくしている原因と思われる。

当初、この修飾型は非常に特異な構造と考えられていた が、CHO 細胞で発現させたヒト IL 12 (11) や thrombospondin type 1 repeat $(12 、 13)$ や補体系 (14)、properdin (15), またヒト尿 中に見い出されている(16)。なかでも properdinにおいては 20 個 のトリプトファンのうち、実に 17 個がマンノシル化されてい

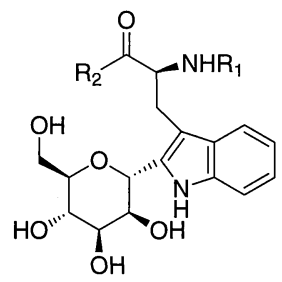

$1 \mathrm{R}_{1}=\mathrm{H}, \mathrm{R}_{2}=\mathrm{OH}$

$2 R_{1}=$ Phe-Thr, $R_{2}=$ Ala-Gln-Trp

$3 \mathrm{R}_{1}=$ Ala-Gln-Trp- $\mathrm{NH}_{2}$

Figure 1. The structures of mannosylated tryptophan 1 and its related peptides 2 and 3. 
mannosylated. Also mannosylated tryptophan 1 was identified in human urine (16). Moreover, mannnosyl-tryptophan 1 was found, not only in higher vertebra, but also in marine ascidians $(17,18)$.

Subsequent studies have revealed that $C$-mannosylation involves the attachment of a mannose residue to the indole moiety of Trp-Xaa-Xaa-Trp (Xaa is any amino acid; glycosylated tryptophan is italicized) as a consensus recognition site (19). Activated donor dolichyl-phosphate mannose is the precursor in the biosynthetic pathway (20), and $C$ mannosyltransferase activity is detected in organisms ranging from C. elegans to humans. Presently, a total of $49 C$ mannosylated tryptophan moieties have been identified, derived from 11 different proteins.

Rapidly growing interest in understanding the molecular mechanisms of biological events involving glycoproteins has resulted in intense attention to protein glycosylation in the last decade. Since glycosylated proteins are not readily available in the homogenous form by gene technological methods, chemical syntheses of precisely defined model glycopeptides are especially important as a valuable tool $(21,22,23)$.

We have recently succeeded in the first total synthesis of $C$-mannosyl tryptophan in a concise stereocontrolled manner $(24,25)$. There are two other examples of $C$-mannnosylated tryptophan $1(16,26,27)$. Herein, we review mannosylated tryptophan science mainly focusing on the synthesis of mannosylated tryptophan $\mathbf{1}$.

\section{B. Synthesis by RIKEN Group $(24,25)$}

We planned a synthetic route to not only synthesize $\mathbf{1}$ but also providing biological probes including its labeled compounds and derivatives. Important points for the successful
る。また脊椎動物だけではなく、昆虫、海綿にも存在すること が明らかになっており、自然界に広く存在していることが予想 されている $(17 、 18) 。$

また、タンパク質側におけるC-マンノース修飾に必要な認 識部位は両末端にトリプトファンを両端に含むテトラペプチド であることも明らかになっている(19)。また、生合成経路におい ての前駆体はドリコールリン酸マンノースである(20)。C-マンノ シル化は転移酵素により触媒されており、この酵素活性は $C$. elegans からヒトにいたるまで幅広く認められる。現在まで 11 の分泌型タンパク質に 49 個の $C$-マンノシル化されたトリプト ファンが見い出されている。

糖ペプチドの化学合成は $N$-結合型糖鎖、 $O$-結合型糖鎖を中 心にさまざまに検討されている $(21 、 22 、 23)$ が、我々はこの新規 $C$-結合型糖アミノ酸； $C$-マンノシルトリプトファン 1, およびそ れを含むぺプチド 2,3 の初の立体選択的合成に成功した $(24 、 25)$ 。 これまでにマンノシルトリプトファンの合成は他に 2 例知 られている(16、26、27)。以下、我々の合成法を中心に述べたい。

B. 理研グループ $(24 、 25)$

生化学的プローブとしても使用することが可能であることを 考慮に入れて短行程、高収率であり、異性体合成、ラベル化合

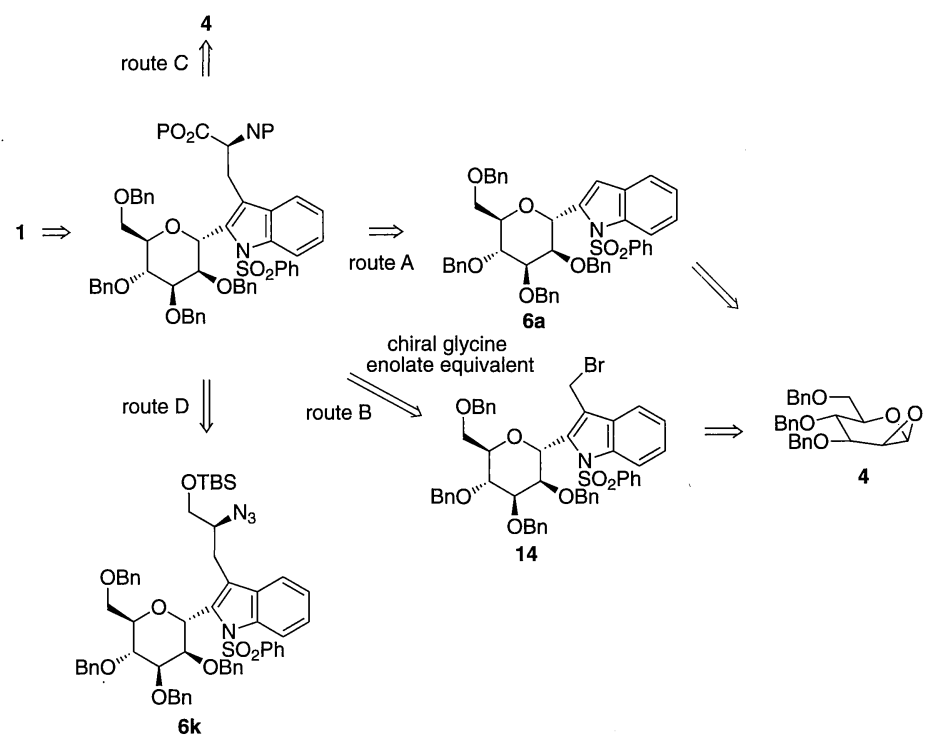

Scheme 1. Synthetic strategies for $1 . \mathbf{P G}=$ protecting group. 
synthesis of $\mathbf{1}$ are: i) construction of a $\mathrm{C}-\mathrm{C}$ bond between the 2position of the indole ring of tryptophan and the anomeric carbon of mannose, and ii) installation of the asymmetric carbon of amino acid (Scheme 1). Although there are several well-established methods for the synthesis of $C$-glycoside, our plan was to directly incorporate the indole ring at the anomeric carbon of mannose. We expected that the coupling between $\mathrm{C}-2$ lithiated indole derivatives and 1,2-anhydro-mannose 4 (28), which is easily obtained from D-mannose in 6 steps, would result in the direct incorporation of the $\mathrm{C}-1$ linked mannose onto the 2-position of indole. Furthermore, because epoxide ring openings by organomethallic reagent are known to proceed via an $\mathrm{SN}_{2}$ pathway, the product was expected have an $\alpha$-configuration. In fact, some studies have demonstrated that nucleophilic attacks on 1,2anhydro- $\beta$-D-mannopyranoses by organometallic reagents gave $\alpha$ - $C$-glycosides (29). $N$-Arylsulfonated indoles 5 have been known to be amenable to direct metallation at the 2-position. Subsequent quenching with an electrophile provides an easy access to 2-substituted indole derivatives (30).

Initially, lithionated 5a was tested as a model substrate (Table I). Contrary to our expectation, the reaction resulted in a mixture of two compounds, which were difficult to separate by silica gel column chromatography (31). However, after removal of the benzyl group and subsequent acetylation, compounds $\mathbf{6 a}$ and 7a were readily separated using silica gel column chromatography. Compound 8 , which was derived from $\mathbf{6 a}$, was confirmed as the $\alpha$-linked product with ${ }^{1} C_{4}$ conformation of the mannopyranoside ring; conversely, 7a corresponded to $\mathbf{9}$, which were assigned as the $\beta$-isomer with ${ }^{4} C_{1}$ conformation (Figure 2).

Using NMR studies, Vliegenthaldt et al. has also reported that the mannnopyranosyl ring of glycopeptide 2 adopted ${ }^{I} C_{4}$
物合成ができるように合成計画をたてた。合成化学的に鍵とな るのはいかにマンノースとインドールをアノマー位不斉炭素の 立体化学を制御してつなげるか、どのようにアミノ酸不斉炭素 を構築するかという点である(Scheme 1)。

まず、インドールとマンノースの炭素結合はマンノースか ら 6 行程で容易に得られる 1,2-アンヒドロマンノース 4 (28) と リチオ化したインドール 5 をルイス酸性条件下反応させて連結 させることとした。エポキシドは通常有機金属試薬と $\mathrm{SN} 2$ 反応 で反応することが知られている。1,2-アンヒドリド糖においても 有機金属試薬とSN2 反応した付加体を与えることが知られてお り (29)、窒素原子を電子吸引性のスルホニルアミド基で保護した インドール誘導体の 2 位をリチオ化して反応させればアノマー 位において望む立体配置の付加体が得られると予想された (30)。まずインドールのスルホニルアミド体 $\mathbf{5 a}$ のリチオ体を1,2アンヒドリド糖 4 と反応させた。 $\mathrm{BF}_{3} \cdot \mathrm{OEt}_{2}$ 存在下、反応は進行 したが、驚いたことに $\alpha$ 体 $\mathbf{6 a}$ と $\beta$ 体 7a の両方の付加体が得ら れた(31)。(水酸基の保護基がベンジル基である場合、シリカゲ ルカラムクロマトグラフィーで異性体を分離することができな かったので、脱保護後、アセチル化してそれぞれを単離した。） また、 $\alpha$ 体 8 に関しては 'H-NMR のアノマー位のカップリング 定数と NOE 実験よりピラン環が反転した ${ }^{1} C_{4}$ 配座をとってい

Table I. Stereoselectivities of the reactions between epoxide 4 and lithiated indole 5 .
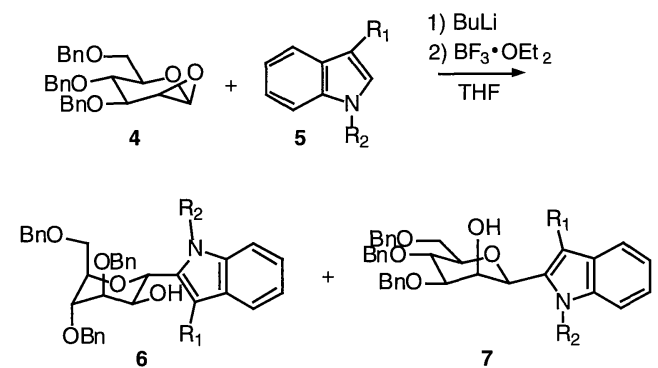

\begin{tabular}{ccccccc}
\hline entry & $\mathbf{6}$ & $\mathrm{R}_{1}$ & $\mathrm{R}_{2}$ & Yield(\%) & products & $\alpha: \beta$ \\
\hline 1 & $\mathbf{a}$ & $\mathrm{H}$ & $\mathrm{SO}_{2} \mathrm{Ph}$ & 39 & $\mathbf{6 a} / 7 \mathbf{a}$ & $69: 31$ \\
2 & $\mathbf{b}$ & $\mathrm{H}$ & $\mathrm{Boc}$ & 49 & $\mathbf{6 b} / 7 \mathbf{b}$ & $34: 66$ \\
3 & $\mathbf{c}$ & $\mathrm{CH}_{3}$ & $\mathrm{SO}_{2} \mathrm{Ph}$ & 39 & $\mathbf{6 c} / 7 \mathbf{c}$ & $87: 13$ \\
4 & $\mathbf{d}$ & $\mathrm{CH}_{3}$ & $\mathrm{Boc}$ & 56 & $\mathbf{6 d} / 7 \mathbf{d}$ & $17: 83$ \\
5 & $\mathbf{e}$ & $\mathrm{CH}_{2} \mathrm{CH}_{3}$ & $\mathrm{SO}_{2} \mathrm{Ph}$ & 38 & $\mathbf{6 e} / 7 \mathbf{e}$ & $>95: 5$ \\
6 & $\mathbf{f}$ & $\mathrm{CH}_{2} \mathrm{OTBS}$ & $\mathrm{SO}_{2} \mathrm{Ph}$ & 50 & $\mathbf{6 f} / 7 \mathbf{f}$ & $>95: 5$ \\
7 & $\mathbf{g}$ & $\mathrm{CH}_{2} \mathrm{OTBS}$ & $\mathrm{Boc}$ & 17 & $\mathbf{6 g} / 7 \mathbf{g}$ & $77: 23$ \\
8 & $\mathbf{h}$ & $\mathrm{CH}_{2} \mathrm{CH}_{2} \mathrm{OTBS}$ & $\mathrm{SO}_{2} \mathrm{Ph}$ & 50 & $\mathbf{6 h} / 7 \mathbf{h}$ & $>95: 5$
\end{tabular}



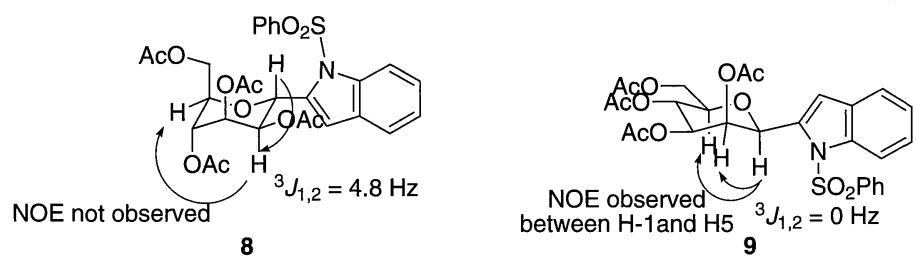

Figure 2. Conformation analyses of 8 and 9 using ${ }^{1} \mathrm{H}-\mathrm{NMR}$ spectroscopy.

conformation (6-9). This unusual conformation can be attributed to two reasons: i) for $C$-glycoside, the absence of the anomeric effect, which is a dominant stereoelectronic factor for $O$-glycosides, and 2) the bulkiness of the indole moiety, which prefers the equatorial conformation.

Further systematic investigations have revealed that the stereoselectivity of epoxide opening is strongly dependent on the nature of the substituents on the nitrogen, as well as the 3position of the indole ring. Representative results are shown in Table I. When sulfonamide was used as a nitrogen-protecting group and the substituent at the 3-position of indole was larger than methyl, the reactions were highly stereoselective, in favor of the a products (Table I, entries 1, 3, 5, 6, and 8). On the other hand, when Boc was used as a protecting group of nitrogen, the $\beta$ product was obtained as a major product (Table I, entries 2,4 , and 7).

From these results, this epoxide ring opening appears to proceed through a mixed SN1/SN2 mechanism (Scheme 2). The significant lack of stereospecificity can be explained as the Lewis acid pre-activating epoxide 4 into oxocarbenium-type intermediate 11, which is subsequently captured by an electrophile in a non-stereospecific manner. However, at this time, we were unable to rationalize the substituent effects on stereoselectivity.

In an attempt to complete the synthesis of $\mathbf{1}$, we undertook the seemingly straightforward reaction between aziridine 13 and indole 12 to introduce the asymmetric center of amino
ることが明らかになった (Figure 2)。これはぺプチド中でのマン ノシルトリプトファンのコンフォメーションも ${ }^{4} C_{l}$ 配座をとら ず、実際にはさまざまなコンフォメーションをとっていること とと一致する(6-9)。これは $C$-グリコシドに $O$-グリコシドに見 られるアノマー効果が存在しないこと、またインドール環がか さ高いためにエクアトリアルの方向を向く方が立体的に有利で あるためである。

種々のインドール誘導体 $\mathbf{5}$ について立体選択性を検討した ところ、窒素原子の保護基がスルホニル基である場合、イン ドール $\beta$ 位の置換基がかさ高くなるにつれて $\alpha$ 選択性が向上 し、逆に Boc 基にすると $\beta$ 選択性が増すことが分かった (Table I)。本反応の立体化学を含めた詳細な反応機構についてはいまだ 不明であるが、期待した SN2 反応ではなく、ルイス酸によりま ず、エポキシドが開環して生じたオキソカルベニウムイオン 11 がインドールリチオ体と反応する SN1 反応、あるいは SN1反応 と SN2 反応の両方のメカニズムで進行していると推測される (Scheme 2)。

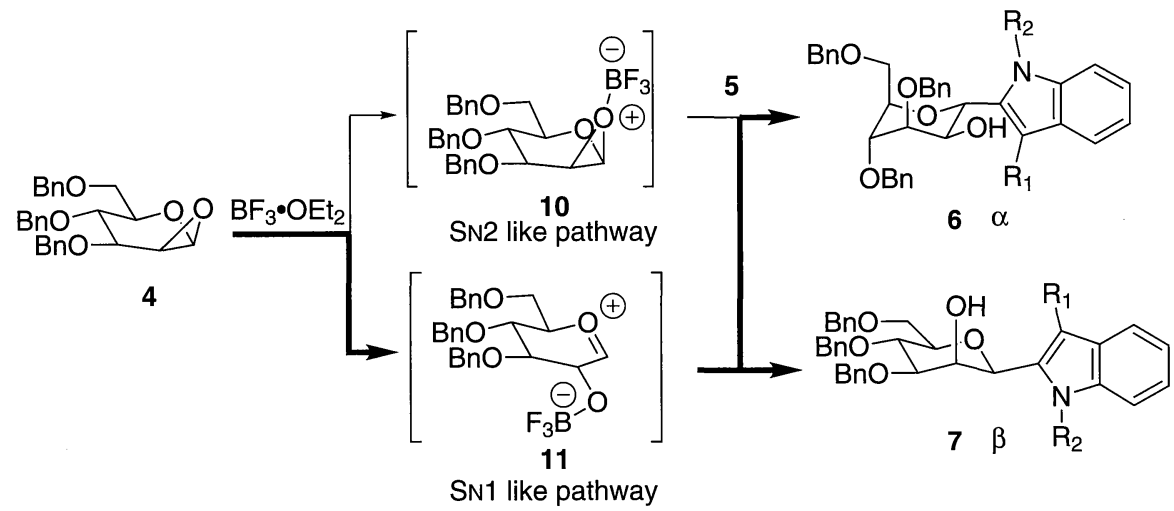

Scheme 2. Mechanisms to explain the stereochemistries of the reactions between 1,2-anhydromannose 4 and lithiated indole derivatives 5 . 
Trends in Glycoscience and Glycotechnology

Vol.15 No.84 (July 2003) pp.181-196
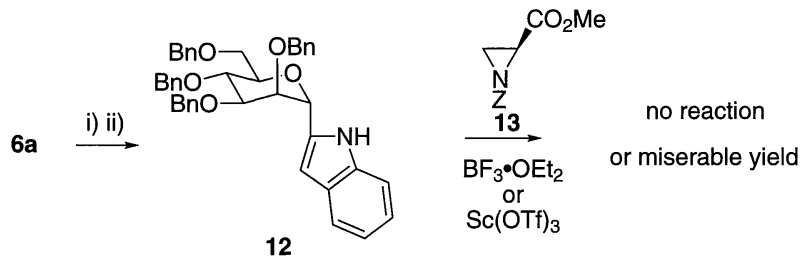

Scheme 3. Reagents and conditions: i) $\mathrm{BnBr}, \mathrm{Bu}_{4} \mathrm{NI}, \mathrm{NaH}$, DMF, r.t., overnight, $87 \%$; ii) $10 \% \mathrm{NaOH}$ aq., EtOH, reflux, overnight, $80 \%$.

acid (Figure 2, route A). However, in the presence of $\mathrm{BF}_{3} \cdot \mathrm{OEt}_{2}(32)$, the reaction did not proceed at all. Although the use of $\mathrm{Sc}(\mathrm{OTf})_{3}$ as an efficient catalyst for this type of reaction was recently reported by Bennani(33), our yields were extremely low when applied to substrate 14 (Scheme 3; Later, this problem was solved by the Nagoya group.).

Since the formation of the $\mathrm{C}-\mathrm{C}$ bond between mannose and tryptophan was successful with $\mathbf{5 f}$, we turned our attention to the synthesis of the amino acid through one-carbon homologation (Figure 2, route B). Since various chiral glycine enolates have been developed, our strategy involved the reaction between enolates 15-18 (34-37) and bromide 14. Following the protection of the 2-hydroxy group as a benzyl ether, the TBS group was removed under acidic conditions, and the resulting alcohol was converted to compound 14 using NBS-PPh ${ }_{3}$ (Scheme 4). However, all four chiral glycine enolates 15-18 did not result in the desired products, presumably because of the steric hindrance of substrate 14.

Since following the indole-mannose coupling with the introduction of the amino acid moiety proved to be highly chal-
ここで、インドール窒素保護基を脱保護した化合物 12 にア ジリジン 13 をルイス酸性条件下反応させればアミノ酸部が導入 できるように思われた (Figure 2, route A)。しかしながら、12に 対しての 13 の反応性がそしく、簡単な基質に関して報告されて いる文献 $(32 、 33)$ に記載されている条件では反応させることが できなかった(Scheme 3)。(名古屋大グループは後にこの問題点 を解決している。)

アミノ酸部を導入するために次にブロミド 14 を調製し、さ まざまなキラルグリシンエノレート等価体 15-18 (34-37) と反応 させ、アミノ酸部を導入することとした (Figure 2, route B)。ブ ロミド $\mathbf{1 4}$ はインドール誘導体 $\mathbf{5 f}$ と 1,2-アンヒドロマンノース 4 を反応させた後、シリル保護基を脱保護し、水酸基を変換さ せて合成した (Scheme 4)。このブロミド 14 とさまざまなキラル<smiles>CCCCOc1c(COCc2ccccc2)c2ccccc2n1-c1cc(O)c(COc2ccccc2)c(O)c1Br</smiles>

i) - iii)

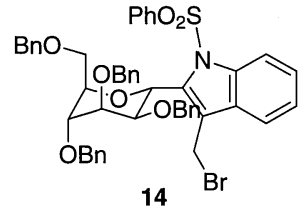

$15-18$

no reaction<smiles>COC1=NC(C(C)C)C(OC)=NC1</smiles>

15<smiles>CC(C)(C)OC(=O)N1CC(=O)OC[C@H]1c1ccccc1</smiles>

16<smiles>CC(C)(C)OC(=O)N1CC(=O)OC(c2ccccc2)C1c1ccccc1</smiles>

17<smiles>COc1ccc(CN2C(=O)CC(=O)N(Cc3ccc(OC)cc3)C2C(C)C)cc1</smiles>

Scheme 4. Reagents and conditions: i) $\mathrm{BnBr}, \mathrm{Bu}_{4} \mathrm{NI}, \mathrm{NaH}, \mathrm{DMF}$, r.t., overnight, $85 \%$; ii) $\mathrm{TsOH} \cdot \mathrm{H}_{2} \mathrm{O}, \mathrm{MeOH}$ r.t., 5h, $90 \%$; iii) $\mathrm{NBS}, \mathrm{PPh}_{3}, \mathrm{CH}_{2} \mathrm{CH}_{2}$, quant. 

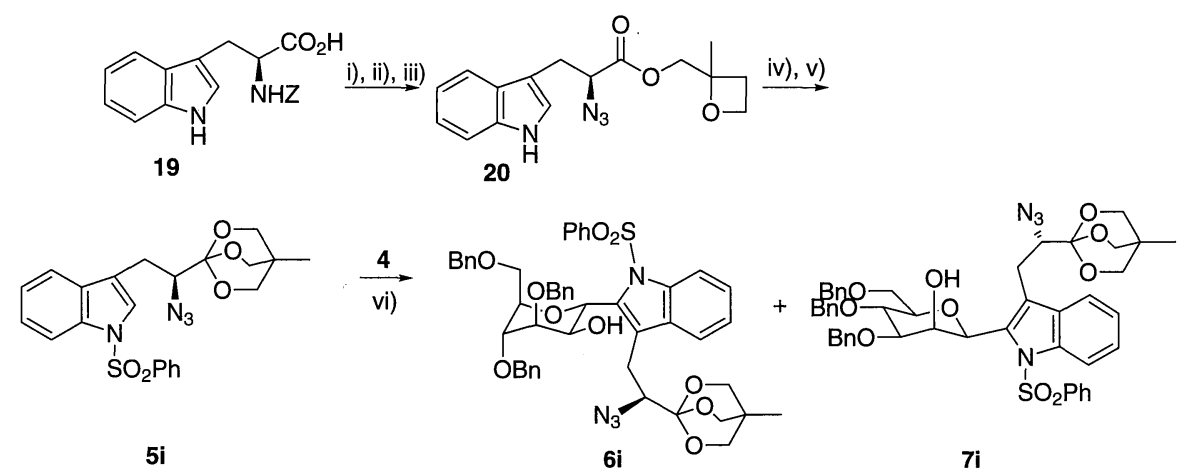

Scheme 5. Reagents and conditions: i) 3-methyl-3-oxetanmethanol, 1-ethyl-3-(3-dimethylaminopropyl)carbodiimide•HCl, DMAP, DMF, r.t., overnight, quant.; ii) $\mathrm{H}_{2}, 10 \% \mathrm{Pd}-\mathrm{C}, \mathrm{MeOH}, 2 \mathrm{~h}$; iii) $\mathrm{TfN}_{3}, \mathrm{DMAP}, \mathrm{CH}_{3} \mathrm{CN}$, r.t., overnight, $79 \%$ (2 steps); iv) $\mathrm{BF}_{3} \cdot \mathrm{OEt}_{2}\left(0.25\right.$ equiv.), $\mathrm{CH}_{2} \mathrm{Cl}_{2}, 34 \%$; v) $\mathrm{PhSO}_{2} \mathrm{Cl}$, BuLi, THF, $-78{ }^{\circ} \mathrm{C}$ - r.t., overnight, $90 \%$; vi) $\mathrm{BuLi}_{1} \mathrm{BF}_{3} \cdot \mathrm{OEt}_{2}, \mathrm{THF},-78^{\circ} \mathrm{C}, 18 \%, 6 \mathrm{i} / 7 \mathrm{i}=55: 45$ (from ${ }^{1} \mathrm{H}$ NMR analysis).<smiles>O=S(=O)(c1ccccc1)n1cc(CBr)c2ccccc21</smiles>

21<smiles>COC1=N[C@H](C(C)C)C(OC)=NC1</smiles>

15<smiles>COC1=N[C@H](C(C)C)C(OC)=N[C@@H]1Cc1cn(S(=O)(=O)c2ccccc2)c2ccccc12</smiles>

5
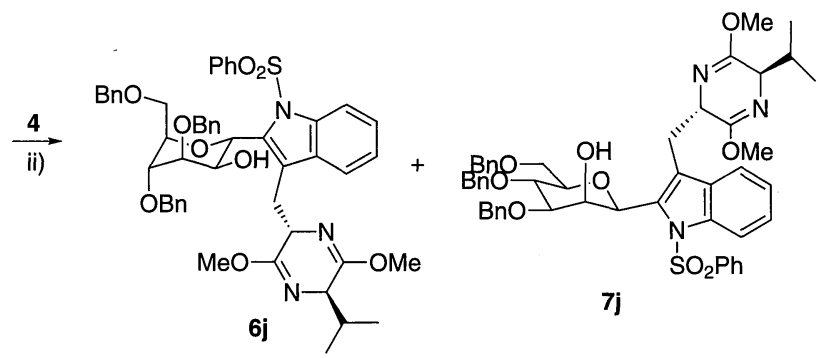

7j

Scheme 6. Reagents and conditions: i) BuLi, THF, $-78{ }^{\circ} \mathrm{C}, 78 \%$; ii) $\mathrm{BuLi}, \mathrm{BF}_{3} \cdot \mathrm{OEt}_{2}, \mathrm{THF},-78^{\circ} \mathrm{C}, 6 \mathrm{j}(10 \%)$ and $7 \mathbf{j}(\mathbf{8 \%})$.

lenging, our third approach involved a coupling reaction between mannose and a fully constructed and masked trytophan, specifically $\mathbf{5 i}$ (Scheme 6) and $\mathbf{5 j}$ (Scheme 7)(Figure 2, route C). In the case of $\mathbf{5 i}$, azide, which is stable under strongly basic conditions, was chosen as the latent amino group. After deprotection of the carbobenzyloxyl group under catalytic hydrogenation conditions, the amino group was transformed to the azide through a diazo transfer reaction, using $\mathrm{TfN}_{3}$, with retention of configuration of the chiral carbon (38). Cyclic 2,6,7trioxabicyclo[2,2,2]octane orthoester was employed as the protecting group for the carboxylic acid because of its stability under strongly basic conditions, such as BuLi, and facile deprotection under mild Brönsted acidic conditions. Following the procedures of Corey (39), orthoester $\mathbf{5 i}$ was prepared from 3-methyl-3-oxetanmethanol ester 20. Alternately, in the case of compound $\mathbf{5 j}$, the amino and the acid groups were protected as the bis-lactim ether ring. As shown in Scheme 6, compound $\mathbf{5 j}$
グリシンエノレート等価体 15-18 とを反応させたが、やはり化 合物 14 の反応性が乏しく目的物はほとんど得られなかった。以 上の結果から、付加した後にインドール側鎖に置換基を導入す るのはおそらく立体的な要因から、困難であることがわかっ た。

そこでアミノ酸不斉炭素部をマスクした形で導入した基質 $\mathbf{5 i}, \mathbf{5 j}$ を用いて付加反応を行うことにした (Figure 2, route C)。こ こでアミノ基とカルボン酸は BuLi を使用する強塩基性条件下安 定である保護基で保護しなければならない。ここでふたつの保 護のパターンが考えられた。ひとつはアミノ基をアジド基とし て保護、一方、カルボン酸を環状オルトエステルとして保護す 

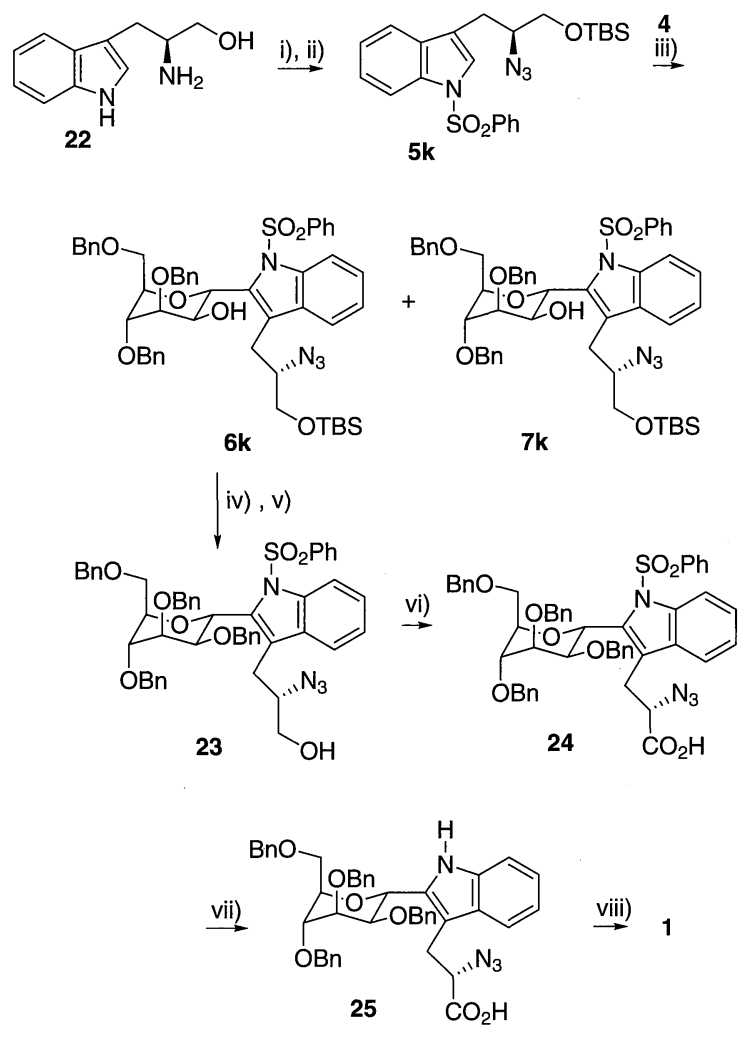

Scheme 7. Reagents and conditions: i) $\mathrm{N}_{3}$ Tf, DMAP, $\mathrm{CH}_{3} \mathrm{CN}$, r.t., overnight, then TBSCl, imidazole, DMF, r.t., overnight, $82 \%$ (2 steps); ii) $\mathrm{PhSO}_{2} \mathrm{Cl}$, BuLi, THF, $-78^{\circ} \mathrm{C}$-r.t., overnight, $75 \%$; iii) $\mathrm{BuLi}, \mathrm{BF}_{3} \cdot \mathrm{OEt}_{2}, \mathrm{THF}, 63 \%$, 6k/7k = 95:5; iv) BnBr, Bu ${ }_{4} \mathrm{NI}, \mathrm{NaH}, \mathrm{THF},{ }^{\circ} \mathrm{C}$-r.t., overnight, $92 \%$; v) $\mathrm{TsOH}^{\circ} \mathrm{H}_{2} \mathrm{O}$, MeOH, r.t., overnight, 91\%; vi) idosobenzene diacetate, TEMPO, $\mathrm{CH}_{3} \mathrm{CN}, \mathrm{H}_{2} \mathrm{O}$, r.t., $3 \mathrm{~h}, 97 \%$; vii) $10 \% \mathrm{NaOH}$, EtOH, reflux, overnight, $68 \%$; viii) $\mathrm{H}_{2}, 20 \% \mathrm{Pd}(\mathrm{OH})_{2} / \mathrm{C}, \mathrm{EtOH}$, dioxane, $\mathrm{H}_{2} \mathrm{O}, 67 \%$.

was prepared from sulfonamide-protected indolyl bromide 21 and Schöllkopf's chiral bis-lactim ether 15. Although the coupling between protected tryptophan derivatives $\mathbf{5 i}$ and $\mathbf{5 j}$ and mannose epoxide $\mathbf{4}$ afforded the desired properly functionalized precursors of the target molecule, the yields and stereoselectivities were unsatisfactory.

The successful strategy (Figure 2, route D) involved indole derivative $\mathbf{5 k}$ as a latent tryptophan moiety, in which the bulky acyclic substituent at the 3-position of the indole ring and sulfonamide as the protection group of the indole nitrogen would enhance $\alpha$-selectivity. As shown in Scheme 7, the straightforward synthesis of 5k from commercially available (L)tryptophanol 22 resulted in high yields. After the amino group was converted to an azide using $\mathrm{TfN}_{3}$, the hydroxyl group was protected as tert-butyldimethylsilyl (TBS) ether. The indole ring was protected as the benzenesulfonamide using benzenesulfonyl chloride and BuLi to give $\mathbf{5 k}$ in $61 \%$ yield (from $\mathbf{2 2}$ ). Subsequent coupling with 1,2-anhydro-mannose 4 proceeded with high selectivity (95:5) and satisfactory efficiency (63\% yield) to afford $6 \mathbf{k}$, along with a small amount of stereoisomer $7 \mathbf{k}$. Benzylation and subsequent removal of the TBS ether under
るパターン 5i である (Scheme 5)。Cbz-トリプトファン 19 を出 発物質としてアミノ基からアジド基への变換は不斉炭素の立体 化学を保持したまま $\mathrm{TfN}_{3}$ を用いてのジアゾ転移反応 (38)によ り行った。環状オルトエステルは Corey らの手法にしたがっ て、3-methyl-3-oxetanmethanol エステル 20 より合成できる(39)。 もうひとつはアミノ基とカルボン酸を bis-lactim エーテルとして 保護するパターン $5 \mathbf{j}$ である (Scheme 6)。これらの基質 $5 \mathbf{i}, 5 \mathbf{j}$ を 1,2-アンヒドロマンノース 4 と反応させたが、両方とも収率、 アノマー位の立体化学の選択性ともに低かった。インドール $\beta$ 位にかさ高い環を持つので反応性が低下したためであると考え られる。

最終的には以下に述べる方法で合成することに成功した (Figure 2, route D, Scheme 7)。すなわち、アミノ基をアジド基と して保護し、カルボン酸は還元して水酸基シリルエーテルとし 

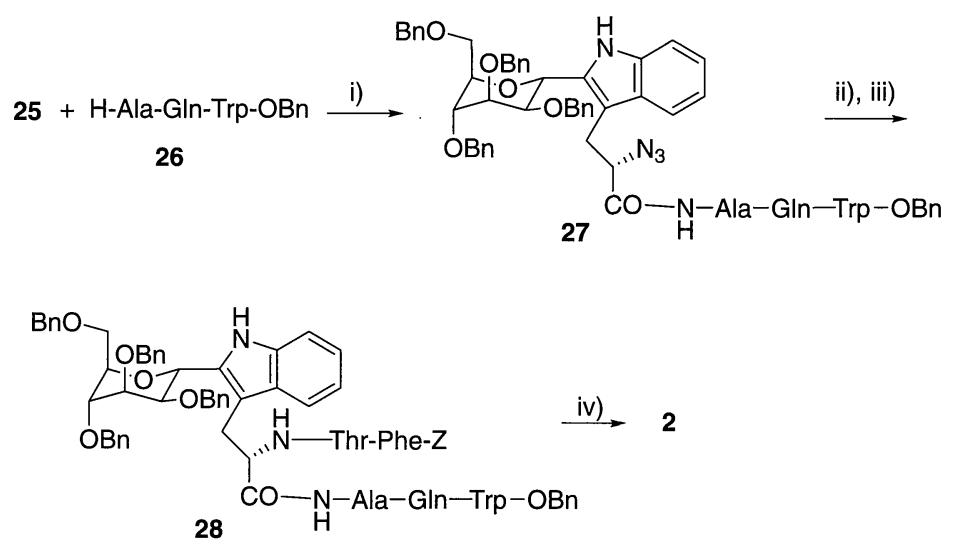

\begin{abstract}
Scheme 8. Reagents and conditions: i) TFFH, $\mathrm{Na}_{2} \mathrm{CO}_{3} \cdot 10 \mathrm{H}_{2} \mathrm{O}, \mathrm{CH}_{2} \mathrm{Cl}_{2}, \mathrm{H}_{2} \mathrm{O}, 90 \%$; ii) $\mathrm{PMe}_{3}$, THF, $\mathrm{H}_{2} \mathrm{O}$, FmocThr-OH, 1-ethyl-3-(3-dimethylaminopropyl)-carbodiimide $\cdot \mathrm{HCl}, \mathrm{HOBt}, \mathrm{CH}_{2} \mathrm{Cl}_{2}, \mathrm{HOBt}, \mathrm{CH}_{2} \mathrm{Cl}_{2}, 84 \%$; iii) piperidine, DMF, Z-Phe-OH, 1-ethyl-3-(3-dimethylaminopropyl)-carbodiimide $\cdot \mathrm{HCl}, \mathrm{HOBt}, \mathrm{CH}_{2} \mathrm{Cl}_{2}, 72 \%$; iv) $\mathrm{H}_{2}, 20 \% \mathrm{Pd}(\mathrm{OH})_{2} / \mathrm{C}, \mathrm{MeOH}, \mathrm{H}_{2} \mathrm{O}, \mathrm{THF}, \mathrm{AcOH}, 57 \%$.
\end{abstract}

acidic conditions afforded $\mathbf{2 3}$ in $91 \%$ yield. With expectations that the strong electron withdrawing nature of the sulfonamide group would protect the indole group from oxidation, attempts to directly oxidize alcohol $\mathbf{2 3}$ to carboxylic acid $\mathbf{2 4}$ were carried out using typical oxidants. A combination of TEMPO and iodosobenzene diacetate (40) was found to afford carboxylic acid $\mathbf{2 4}$ directly from $\mathbf{2 3}$ in excellent yields. Usually, the indole group is sensitive to the oxidation conditions, electron withdrawing sulfonyl group protected the indole group by deducing the electron density.

A two-step deprotection from $\mathbf{2 5}$ was accomplished with concurrent reduction of the azide group. Final purification was performed using reverse-phase silica gel column chromatography $\left(\mathrm{H}_{2} \mathrm{O} / \mathrm{MeOH} 4: 1\right)$ or size exclusion column chromatography (Bio-Gel P-2 gel, extra fine, $\mathrm{H}_{2} \mathrm{O} / \mathrm{MeOH}$ 9:1). ${ }^{1} \mathrm{H}-\mathrm{NMR}$ data of synthetically derived 1 (in $\mathrm{D}_{2} \mathrm{O} ;{ }^{3} J_{1,2}=8.1 \mathrm{~Hz}$ ) clearly showed that the mannose ring generally adopts the ${ }^{1} C_{4}$ conformation, with the tryptophan moiety in the equatorial position; the NMR data is in good agreement with those reported for mannosyltryptophan containing peptides.

With attainment of homogeneous synthetic 1 , we consequently undertook the synthesis of hexapeptide $\mathbf{2}$, which corresponds to residues 5-10 of Human RNase Us. As shown in Scheme 8 , intermediate 25 was proposed as the building block for $C$ mannosyl tryptophan. Azide acids, which do not form oxazolones, can be used for peptide synthesis without likelihood of racemization (41). The peptide bond formation between azide acid 25 and tripeptide $\mathbf{2 6}$ was performed using tetramethylfluoroformidium hexafluorophosphate (TFFH) mediated in situ acid fluoride formation protocol to provide tetrapeptide $\mathbf{2 7}$ in $90 \%$ yield. After selective reduction of the azide group using $\mathrm{PMe}_{3}$, subsequent coupling reactions with Fmoc-Thr-OH and Z-Phe-OH were suc-
て保護した。アミノ基を $\mathrm{TfN}_{3}$ を用いてアジド基へ変換し、イン ドール窒素の保護基は $\alpha$ 選択性を高くするために表 I で得られ た結果からスルホニル基で保護することとした。このインドー ル誘導体 5k と 1,2-アンヒドロ糖 $\mathbf{4}$ との反応は収率よく進行し、 期待した通りに $\alpha$ 体 $\mathbf{6 k}$ を優先的に生じた。 2 位の水酸基をべ ンジルエーテルとして保護し、シリル基を脱保護して生じた水 酸基を一気に TEMPO-BAIB (40) によりカルボン酸 $\mathbf{2 4}$ へと酸化 した。一般にインドールは酸化反応などに敏感であるが、強い 電子吸引性の $\mathrm{SO}_{2} \mathrm{Ph}$ 基がインドール環の電子密度を低下させて いるために安定であった。最後に $\mathrm{SO}_{2} \mathrm{Ph}$ 基をアルカリ性条件で 脱保護し、接触水素添加条件でベンジル基を脱保護するととも にアジド基を還元し、目的物であるC-マンノシルトリプトファ ン 1 を得ることができた。C-マンノシルトリプトファンは ${ }^{1} \mathrm{H}-$ NMR で重水中アノマー位の水素の結合定数 $J$ が $8.1 \mathrm{~Hz}$ である ことから、 ${ }^{{ }^{2} C_{4}}$ 配座を優先してとることが分かった。

また、中間体アジド酸 $\mathbf{2 5}$ は C-マンノシルトリプトファンを 含むぺプチド合成に有用な中間体となる。アジド基はカルボン酸 が活性化されたときに隣接基関与しないのでラセミ化が問題とな らない利点がある(41)。アジド酸 25 と保護したトリペプチド 26 とのアミド結合形成反応は TFFH (tetramethylfluoroformidium hexafluorophosphate)(42)を用いてフッ化物を経ることにより収率 

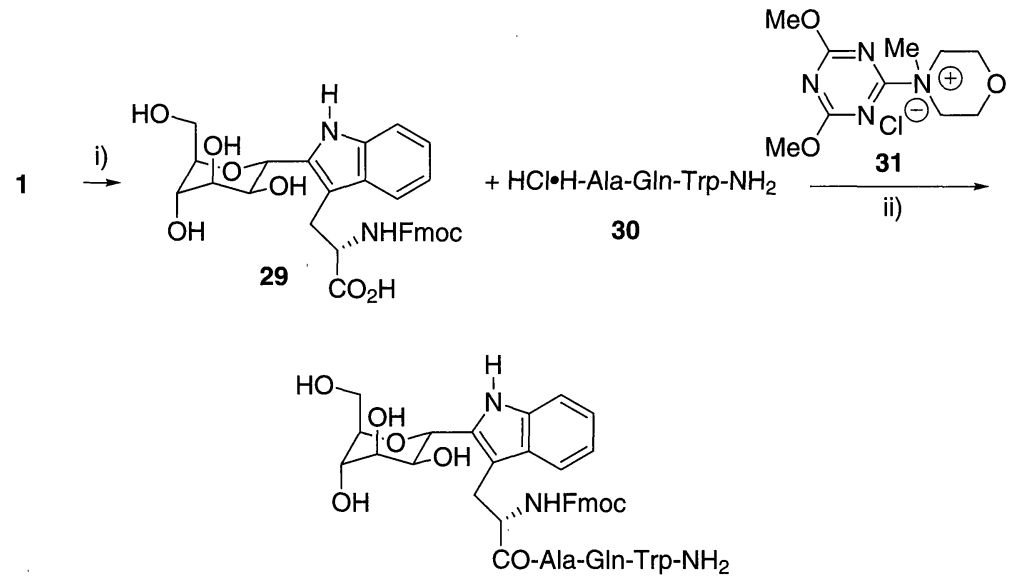

32

\section{Scheme 9. Reagents and conditions: i) Fmoc-OSu, $\mathrm{NaHCO}_{3}, \mathrm{DME}, \mathrm{H}_{2} \mathrm{O}, 67 \%$; ii) 31, $\mathrm{MeOH}, 94 \%$.}

cessfully carried out to afford $\mathbf{2 8}$ in good yields. The final deprotection of compound $\mathbf{2 8}$ was performed under mild catalytic hydrogenation conditions using $\mathrm{Pd}(\mathrm{OH})_{2} / \mathrm{C}$ to yield product 2 , which was purified by gel filtration column chromatography (Sephadex LH-20, MeOH).

A more concise approach to glycopeptide synthesis is based upon minimal protection strategy, in which only the side chain carboxylic acid and amino groups are protected. Because of the large differences in reactivities between amino and hydroxyl groups, protection of the hydroxyl groups of the sugar moiety may be omitted. We turned our attention to a novel amide formation protocol that is compatible with hydroxyl groups, which features 4-(4,6-dimethoxyl-1,3,5-triazie-2-yl)-4-methyl-
$90 \%$ で行った (Scheme 8)。その後、アジド基をトリメチルホス フィンにより選択的に還元し、さらにペプチドを Fmoc 法によ り伸長し、最後に接触還元により、最終脱保護を行い、最初に 同定された human RNase Us の部分構造 2 を合成した。また $C$ マンノシルトリプトファン 1 のアミノ基を Fmoc 基で保護した 化合物 29 はトリアジン誘導体 $31(43 、 44)$ を用いると撖密な反 応条件の設定を行わなくとも水酸基を無保護のままアミド結合 を形成できる(Scheme 9)。この方法を用いて、認識部位である

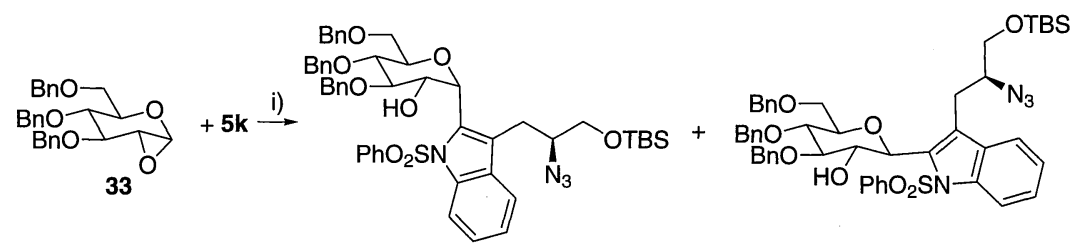

34

35

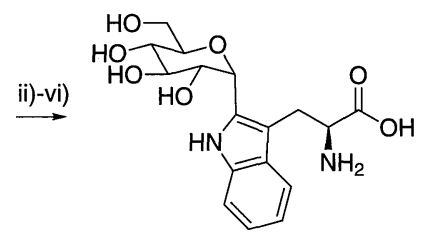

36

Scheme 10. Reagents and conditions: i) BuLi, $\mathrm{BF}_{3} \cdot \mathrm{OEt}_{2}$, THF, 34 (10\%) and 35 (2\%); ii) $\mathrm{BnBr}, \mathrm{Bu}_{4} \mathrm{NI}, \mathrm{NaH}$, $\mathrm{THF}, \mathrm{O}^{\circ} \mathrm{C}$, r.t., overnight, $77 \%$; iii) $\mathrm{Ts} \mathrm{OH} \cdot \mathrm{H}_{2} \mathrm{O}, \mathrm{MeOH}$, r.t., overnight, $99 \%$; iv) idosobenzene diacetate, TEMPO, $\mathrm{CH}_{3} \mathrm{CN}, \mathrm{H}_{2} \mathrm{O}$, r.t., $3 \mathrm{~h}, 85 \%$; v) $10 \% \mathrm{NaOH}$, EtOH, reflux, overnight, 56\%; v) $\mathrm{H}_{2}, 20 \% \mathrm{Pd}(\mathrm{OH})_{2} / \mathrm{C}$, EtOH, dioxane, $\mathrm{H}_{2} \mathrm{O}, 65 \%$. 
morfolinium chloride 31 (42) (Scheme 9). Compound 31 was reported to be effective for amide bond formation in protic solvents $(43,44)$. The amino group of mannosyl tryptophan was protected with Fmoc in the usual manner in $68 \%$ yield. By this method, the recognition sequence tetrapeptide with mannose $\mathbf{3 2}$ was synthesized. The advantage of this procedure is that the carboxylic acid can be used directly without previous activation.

Using similar procedures as described above, glucosyl tryptophan 36, which is a steroisomer of mannosyl tryptophan, was synthesized (Scheme 10).

\section{Identification, Synthesis, and Immunoassay by Kyowa- medex. Co. and Marine Biotechnology Institute Co.}

$C$-Mannosyltryptophan $\mathbf{1}$ was discovered in human urine after HPLC analysis of various biological samples. This compound was then synthesized and antibodies against it were produced.

After preprocessing, purification was repeated using a Sephadex G-25 super fine column, a positive ion-exchange resin Sepharose fast-flow column, a negative ion-exchange resin DEAE-Sepharose column and a reverse phase column. From $500 \mathrm{~L}$ of urine, $5 \mathrm{mg}$ of 1 was obtained. At a measurement wavelength of $350 \mathrm{~nm}$, there was a favorable linear correlation between fluorescence intensity and concentration of $\mathbf{1}$, and it was found that $\mathbf{1}$ could be quantified using $N$-methylserotonin as an
テトラペプチドにマンノースが付加した化合物 32 を合成した。

また、 $C$-Man-Trp と同様のストラテジーにより立体異性体 である C-グルコシルマンノース 36 についても合成することが できた (Scheme 10)。

本合成は類縁体、ラベル化合物などの合成も可能である柔 軟性のある合成ルートである。

C. 協和メデックス・海洋バイオテクノロジーグループ(16)

彼等は HPLC で生体試料中の種々の化合物を分析中、ヒト 尿中に 1 が存在することを見い出した。彼等は 1 を合成すると ともにそれに対する抗体を作成した。

尿からは前処理後、セファデックス G-25 スーパーファイン カラム、陽イオン交換樹脂セファロースファーストフローカラ ム、陰イオン交換樹脂 DEAE-セファセルカラム、逆相カラムク ロマトグラフィーによる精製を繰り返し、500 l の尿から $5 \mathrm{mg}$ のマンノシルトリプトファン 1 を得た。測定波長 $350 \mathrm{~nm}$ にお いて 1 の蛍光強度と濃度は良好な直線関係を示し、N-メチルセ ロトニンを内部標準として1を定量することが可能であること

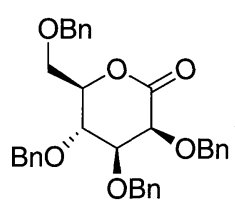

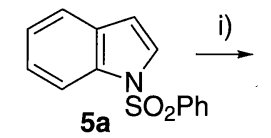

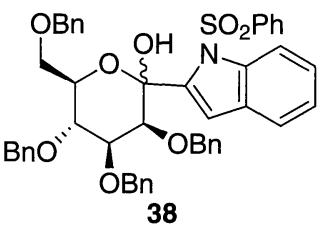

37

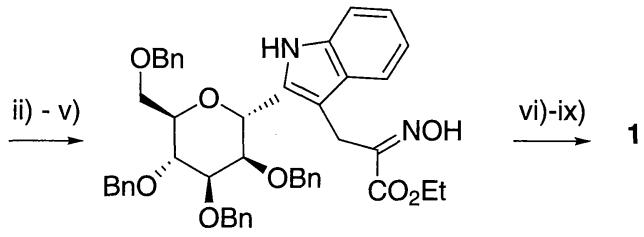<smiles>CCOC(CBr)=NO</smiles>

Scheme 11. i) LDA, THF, toluene, $-78{ }^{\circ} \mathrm{C}, 30 \mathrm{~min}, 47 \%$; ii) LAH, THF, $0{ }^{\circ} \mathrm{C}, 30 \mathrm{~min}, 75 \%$; iii) TsOH•H${ }_{2} \mathrm{O}$, toluene, $1 \mathrm{~h}, 58 \%$, diastereomer ratio 1.4:1; iv) $50 \% \mathrm{NaOH}, \mathrm{EtOH}, 100{ }^{\circ} \mathrm{C}, 1 \mathrm{~h}, 76 \%$; v) $40, \mathrm{Na}_{2} \mathrm{CO}_{3}, \mathrm{CH}_{2} \mathrm{Cl}_{2}$, r.t., $1.5 \mathrm{~h}, 37 \%$; vi) $\mathrm{Al}-\mathrm{Hg}$, THF, $55^{\circ} \mathrm{C}, 0.5 \mathrm{~h}, 90 \%$, diastereomer ratio 1.6:1; vii) $\mathrm{ZCl}, \mathrm{Et}_{3} \mathrm{~N}, \mathrm{CHCl}_{3}$, toluene, $20{ }^{\circ} \mathrm{C}, 15 \mathrm{~min}, 95 \%$; viii) $\mathrm{LiOH} \cdot \mathrm{H}_{2} \mathrm{O}$, dichloroethane, $\mathrm{H}_{2} \mathrm{O}$, r.t., $16 \mathrm{~h}, 40 \%$; ix) $\mathrm{H}_{2}, 20 \% \mathrm{Pd}(\mathrm{OH})_{2} / \mathrm{C}, \mathrm{EtOH}, 60$ ${ }^{\circ} \mathrm{C}, 11 \mathrm{~h}, 62 \%$. 
internal standard. With this method, the level of $\mathbf{1}$ in healthy men and women aged up to 90 years has been measured at 76.3 and $74.5 \mathrm{ng} / \mathrm{ml}$, respectively, while that in patients with nephropathy has been measured at about $850 \mathrm{ng} / \mathrm{ml}$. In addition, the level of $\mathbf{1}$ in the spinal fluid of healthy individuals has been measured at $130.4 \mathrm{ng} / \mathrm{ml}$, while that of patients with spinocerebellar degeneration has been measured higher at $400 \mathrm{ng} / \mathrm{ml}$ and patients with metastatic brain tumor $823 \mathrm{ng} / \mathrm{ml}$. Furthermore, the level of $\mathbf{1}$ in the amniotic fluid of healthy individuals has been measured at $353 \mathrm{ng} / \mathrm{ml}$, but that of patients with pregnancy toxemia has been measured much higher at $1411 \mathrm{ng} / \mathrm{ml}$.

With regard to synthesis, lithioindole $\mathbf{5 a}$ is first added to lactone 37, which is derived from mannose. After reducing the resulting lactol 38, cyclo-dehydration is conducted under acidic conditions (Scheme 11). The hemiacetal of lactol $\mathbf{3 8}$ can be also directly reduced using $\mathrm{Et}_{3} \mathrm{SiH}-\mathrm{BF}_{3} \cdot \mathrm{OEt}_{2}$, but the yield is low $(16 \%)$. The nitrogen-protecting group of indole is deprotected under basic conditions. An amino acid moiety is introduced using 40 in the presence of $\mathrm{Na}_{2} \mathrm{CO}_{3}$. As the amino group is protected as an oxime, $\mathbf{1}$ is obtained through a sequence of reduction of the oxime by $\mathrm{Al}$ amalgam, protection of the amino group by the benzyloxycarbonyl group, deprotection of the carboxylate ester, and finally deprotection based on catalytic hydrogenation. Numerous points need to be improved, such as stereoselectivity of cyclization in an acidic environment, stereoselectivity of oxime reduction, hydrolysis of the ester of the carboxylate protecting group, and racemization of the asymmetric carbon atoms in the amino acid region.

Synthesized 1 (strictly speaking, a mixture of isomers at asymmetric carbon atoms in the amino acid moiety) was bound to either KLH (keyhole limpet hemocyanin) or BSA (bovine serum albumin) using EDC. Mice were immunized against these haptens to produce antibodies. Then, hybridoma was produced using antibody-producing cells and mouse myeloma cells (P3U1). After cloning, purified antibodies were obtained from the mice. These antibodies were used to measure the levels of $\mathbf{1}$ in urine and serum samples by ELISA. The results showed that, regardless of age or gender, the amount of $\mathbf{1}$ excretion was comparable, thus suggesting that it could be used as a new glomerular filtration indicator instead of creatinine clearance or inulin clearance. The present study is very interesting because mannosyltryptophan $\mathbf{1}$ was not only synthesized, but its practical application was also suggested.

\section{Synthesis by Nagoya Group $(26,27)$}

Isobe's group has designed and developed their original $C$-alkynylation method, and applied the methodology to the natural product synthesis such as Okadaic acid (45). They reported the synthesis of $C$-mannosyl-tryptophan 1 through their original alkyne $C$-glycosylation method and indole construction by use of palladium chemistry (26). The alkyne $\mathbf{4 2}$ reacts
を見い出した。その方法を用いることにより新生児から 90 歳ま での健常人では男性 $76.3 \mathrm{ng} / \mathrm{ml}$ 、女性 $74.5 \mathrm{ng} / \mathrm{ml}$ の 1 が尿中に 存在するのに対し、腎臓疾患患者では約 $850 \mathrm{ng} / \mathrm{ml}$ の 1 が存在 することが確かめられた。また、髄液中では健常人で $130.4 \mathrm{ng} /$ $\mathrm{ml}$ で存在するのに対し、脊髄小脳変性患者では $400 \mathrm{ng} / \mathrm{ml}$ 、転 移性脳腫瘍患者では $823 \mathrm{ng} / \mathrm{ml}$ の高值を示した。また、羊水中 においては健常者では $\mathbf{1}$ が $353 \mathrm{ng} / \mathrm{ml}$ で含まれるのに対し、妊 娠中毒症患者では $1411 \mathrm{ng} / \mathrm{ml}$ で含まれている。

合成はまず、マンノースから誘導されるラクトン 37 にリチ オ化したインドール 5a を付加させ、生じたラクトール 38 を還 元した後、酸性条件で脱水環化させている(Scheme 11)。ラクト ール 38 を $\mathrm{Et}_{3} \mathrm{SiH}_{-}-\mathrm{BF}_{3} \cdot \mathrm{OEt}_{2}$ により還元することもできるが収率 が低い $(16 \%)$ ○イントールの窒素保護基をアルカリ性条件で脱 保護し、 $\mathrm{Na}_{2} \mathrm{CO}_{3}$ 存在下 40 を用いてアミノ酸部を導入している。 アミノ基はオキシムとして保護しているが、オキシムの $\mathrm{Al}$ アマ ルガムによる還元、ベンジルオキシカルボニル基によるアミノ 基の保護、カルボン酸エステルの脱保護を経て、最終的に接触 水素添加により、脱保護を行い、1を得ている。しかしながら 酸性条件においての環化反応の立体選択性、オキシムの還元の 立体選択性、またカルボン酸保護基のエステル加水分解のさい にアミノ酸部不斉炭素のラセミ化が見られる点など改善すべき 点は多い。

彼等は合成した 1 (厳密にはアミノ酸不斉炭素に関して両異 性体の混合物)を KLH (キーホールリンペットヘモンシアニン)、 あるいはBSA (ウシ血清アルブミン)に EDCを用いて結合させ た。これらのハプテンをマウスに免疫し、抗体を産生させた。 この抗体を産生細胞とマウスミエローマ細胞 P3U1 からハイブ リドーマを作成した。クローニングを行い、精製抗体をマウス から取得した。これら抗体を用いて ELISA 法により尿中、血 清中の 1 の存在量を測定した。その結果、老若男女を問わず、 1 の排出量がある一定の限局した值をとり、腎系球体滤過量を はかる指標であるイヌリンクリアランス法あるいはクレアチニ ンクリアランス法にかわる新しい指標となる可能性を提示して いる。マンノシルトリプトファン 1 の合成だけではなく、実際 に臨床にも応用できる可能性を示した点で非常に興味深い。

\section{D. 名古屋大グループ(26、27)}

名古屋大学磯部グループでは以前から糖にアルキン誘導体 をアノマー位に $\alpha$ 選択的に導入する優れた方法を開発して拀 り、その手法を Okadaic acid に代表されるさまざまな天然物合 成に精力的に応用してきた(45)。この手法を基盤としてC-マンノ シルトリプトファン 1 の合成を行っている。

彼等はまずはじめに下マンノース誘導体 41 とシリルアセチ レン 42 を TMSOTf 存在下反応させて $C$-グリコシドを $\alpha$ 立体選 
<smiles>C#C[C@H]1OC(COC(C)=O)[C@H](O)[C@H](O[C@H](Cc2ccccc2)c2ccccc2)[C@H]1OCc1ccccc1</smiles><smiles>CC(=O)OCC1O[C@H](c2cc3ccccc3n2Cc2ccccc2)[C@H](O)[C@H](OCc2ccccc2)[C@H]1OCc1ccccc1</smiles>

45<smiles>CC(=O)OCC1O[C@H](c2[nH]c3ccccc3c2C=O)[C@H](O)[C@@H](OCc2ccccc2)[C@@H](O)C1Cc1ccccc1</smiles>

46<smiles>CCNC(=Cc1c([C@H]2O[C@H](COC(C)=O)[C@@H](Cc3ccccc3)[C@H](OCc3ccccc3)[C@H]2Cc2ccccc2)[nH]c2ccccc12)C(=O)OCC</smiles>

47

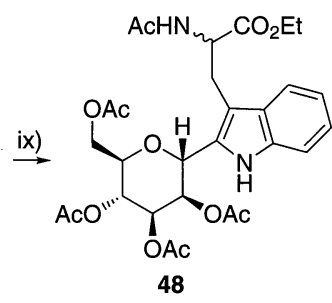

$\mathrm{TMS}-\frac{\overline{\overline{42}}}{\mathrm{SnBu}_{3}}$

\begin{abstract}
Scheme 12. i) 42, TMSOTf, $\mathrm{CH}_{2} \mathrm{Cl}_{2}$; ii) TBAF, aq. THF, $91 \%$ (2 steps); iii) $o$-PhINHTs, Pd(OAc), $\mathrm{Ph}_{3} \mathrm{P}, \mathrm{CuI}, \boldsymbol{n}$ butylamine, THF, 96\%; iv) CuI, $\mathrm{Et}_{3} \mathrm{~N}$, DMF, 80\% ; v) TBAF, THF, vi) $\mathrm{POCl}_{3}$, DMF; aq. KOH; vii) $\mathrm{Ac}_{2} \mathrm{O}$, pyridine, 88\% (3 steps); viii) AcHNCH(COOH)COOEt, $\mathrm{Ac}_{2} \mathrm{O}$, pyridine, 66\%; ix) $\mathrm{H}_{2}, \mathrm{Pd}-\mathrm{C}$, MeOH, $64 \%$.
\end{abstract}

with mannose derivative $\mathbf{4 1}$ in the presence of TMSOTf to give the adduct. After desilylation, the compound $\mathbf{4 3}$ was obtained with complete $\alpha$-selectivity. The indole ring was installed by use of Sonogashira's conditions (46) and Castro indole synthesis (47). After deprotection of tosyl group, aldehyde $\mathbf{4 6}$ was synthesized by Vilsmeier reaction. Then, aldehyde 46 was condensed with acetamide malonate monoethylester to give olefin $\mathbf{4 7}$ and hydrogenation of olefin $\mathbf{4 7}$ to give inseparative diastereomeric mixtures at asymmetric center $\mathbf{4 8}$.

Then they turned their attention to the use of aziridine $\mathbf{1 3}$ to install the asymmetric carbon center (27). Boron etherate and lanthanide triflate is reported to be an effective Lewis acid for the aziridine opening $(32,33)$. However, these Lewis acids did not give satisfactory results. Then, they investigated fully about the suppliers and preparation method of lanthanide triflate. Finally, they found that $\mathrm{Sc}\left(\mathrm{ClO}_{4}\right)_{3}$ was the effective Lewis acid for the reaction between 13 and $\mathbf{4 9}$ (48). After three-step deprotection procedure, the target molecule $\mathbf{1}$ was obtained.

Furthermore, they attempted synthesis of glucosyl-tryptophan (49). They commenced with the synthesis by preparation of compound 51. Iodoacetylene $\mathbf{5 1}$ was coupled with (L)-
択的に得た(Scheme 12)。シリル基を脱保護した後、溒頭反応 (46)、Castro 反応 (47)によりインドール環を収率よく得た。卜 シル基を脱保護後、Vilsmeier 反応によりアルデヒドを導入し た。アルデヒド 46 と acetamide malonate monoethylester ととの 縮合反応の後、生じたオレフィンを水素添加することにより、 アミノ酸部の不斉炭素に関して $2 つ$ つジアステレオ混合物 $\mathbf{4 8}$ が 得られた。しかしながらこれらを分離することは困難であった (26)。

$$
\text { そこで彼等はアジリジン } 13 \text { を用いてルイス酸条件下アミノ }
$$
酸部を導入することを試みた(Scheme 13)。インドールの $\beta$ 位に アジリジン 13 を付加させる反応において当初は $\mathrm{BF}_{3} \cdot \mathrm{OEt}_{2}$ が用 いられていたが (32)、その後、ランタノイドトリフラートが有 効であることが報告されている (33)。しかしながら、これらの 試薬では 49 に対して十分な結果を得ることができず、彼等は 様々なランタノイドトリフラートの購入先、調整法について詳 細に検討し、 $\mathrm{Sc}\left(\mathrm{ClO}_{4}\right)_{3}$ が最良の結果を与えることを見い出した (48)。3 段階の脱保護反応を行い、マンノシルトリプトファン 1 を得ている(27)。

さらにグルコース誘導体合成を行うべく(49)、糖アセチレン 誘導体 51 から Jackson らの手法 (50)により (L)-セリンから誘導 した亜鉛-銅試薬 52 を用いてあらかじめアミノ酸不斉炭素を導 

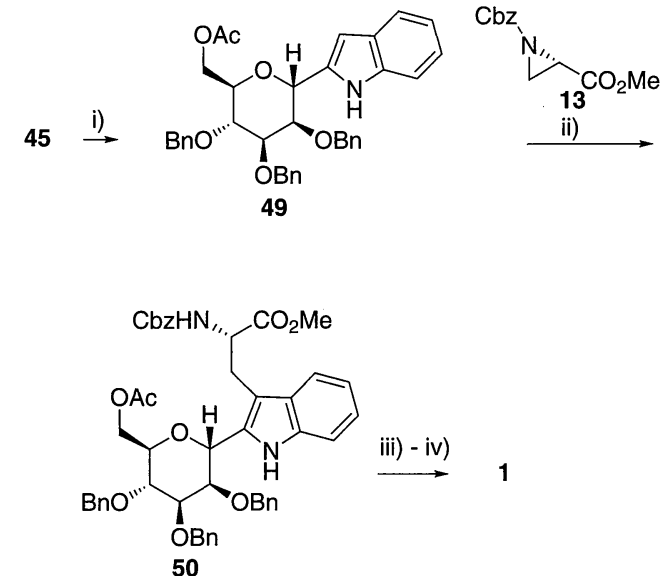

\section{Scheme 13. i) TBAF, THF, ii) $\mathrm{Sc}\left(\mathrm{ClO}_{4}\right)_{3}, \mathrm{CH}_{2} \mathrm{Cl}_{2}, 0{ }^{\circ} \mathrm{C}, 66 \%$; iii) aq. $\mathrm{LiOH}, i-\mathrm{PrOH}, 62 \%$; iv) $\mathrm{H}_{2}, \mathrm{Pd}(\mathrm{OH})_{2} / \mathrm{C}$, $\mathrm{HCl}, \mathrm{MeOH}, 50 \%$.}
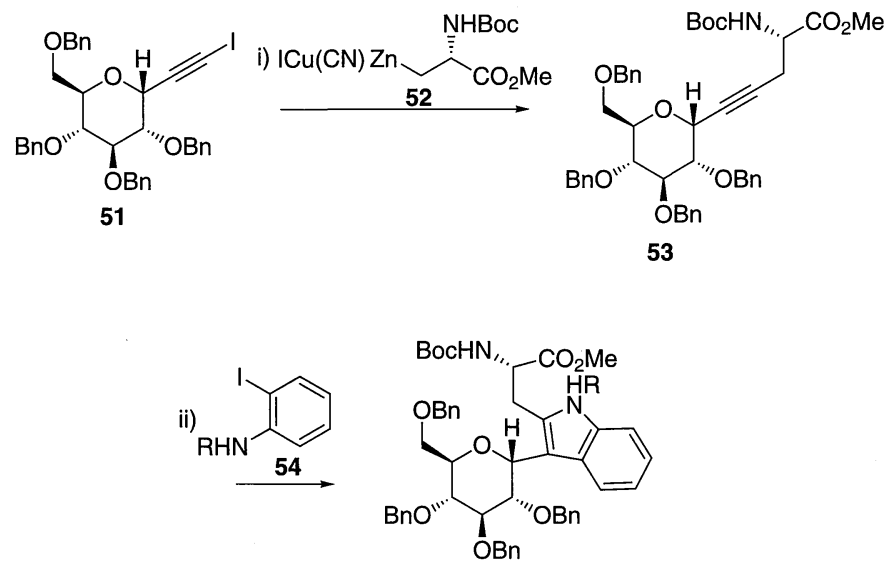

55

Scheme 14. i) THF, $-78-4^{\circ} \mathrm{C}, 12 \mathrm{~h}, 43 \%$; ii) $\mathrm{Pd}(\mathrm{OAc})_{2}, \mathrm{PPh}_{3}, n-\mathrm{Bu}_{4} \mathrm{NCl}, \mathrm{Na}_{2} \mathrm{CO}_{3}, \mathrm{DMF}, 100{ }^{\circ} \mathrm{C}, 24 \mathrm{~h}, 89 \%(\mathrm{R}=\mathrm{Ts})$.

serine derived zinc-copper reagent $\mathbf{5 2}$, which was developed by Jackson (50). They made an attempt to annulate indole by Larock's procedure using $o$-iodoaniline 54. Unfortunately, the product 55 was the iso-tryptophan, not the desired tryptophan. Although Larock suggested the regioselectivity of this annulation was controlled by steric balance between two substituents of acetylene to afford a product having a sterically hindered substituent at the 2-position of indole in high selectivity $(51,52$, 53), this is the first example of complete reverse regioselectivity in Larock's heteroannulation.

\section{E. Conclusion}

The report described the various tissues surrounding synthesis of $C$-mannosyltryptophan. At present, even with the GlycoSuite Database (54), $C$-bound sugar chains are recognized as one of the categories and are being more widely accepted. Mannosylated peptides are also known to improve resistance
入し、Larock らのインドール合成法 (51) により環化することを 試みた (Scheme 14)。Larock は環化反応の位置選択性がアセチレ ンの置換基により変化することを見出している(51、52、53)が、し かしながら非常に興味深いことに得られたものは環化反応にお いて位置選択性が完全に逆転したiso-インドール体 55 であっ た。インドール窒素の保護基 $\mathrm{R}$ が環化の収率に大きく影響を及 ぼすことも興味深い。

\section{E. 結 論}

以上、C-マンノシルトリプトファンの合成を中心について 述べた。現在は GlycoSuite database (54) にも $C$-結合型糖鎖はカ テゴリーのひとつとして認知されるに至っており、市民権を得 つつあるようにみえる。今後の研究の発展が望まれる。また、 マンノシル化されたペプチドは chymotrypsin, carboxypeptidases 
Trends in Glycoscience and Glycotechnology

against chymotrypsin, carboxypeptidase $\mathrm{A}$, carboxypeptidase $\mathrm{Y}$ or Aminopeptidase M (10), but the biological significance of $C$ bound sugar chains has yet to be elucidated. In any case, future research is needed to ascertain whether the sequences recognized by mannosylated peptides resemble WS Box (WSXWS), which is common to cytokine Class I receptors, and whether mannosylated peptides are universal to membrane proteins because their correlation to certain diseases has been documented (55).

\section{Acknowledgments}

This work was supported by the Special Researcher's Basic Science Program at RIKEN, the Novartis Foundation (Japan) Mizutani Foundation and Grant-in-Aid for Scientific Research from the Japan Society for the Promotion of Science (Grant No. 13480191). We thank Ms. A. Takahashi for technical assistance. We thank Dr. J. Uzawa, Dr. H. Koshino and Ms. T. Chijimatsu for recording and measuring the NMR spectra. We thank Dr. Chihara and his staff for elemental analysis.

A, carboxypeptidase $\mathrm{Y}$ や Aminopeptidase $\mathrm{M}$ に対しての耐性が高 まることなどはわかっている(10)ものの $C$-結合型糖の生物学的 存在意義はいまだ未解明である。しかしマンノシル化が揖こる ペプチドの認識配列がサイトカイン Class I レセプターに共通し てみられるWS ボックス (WSXWS) と類似していたり、膜タン パクに普遍的に存在するかどうかも興味深く、疾患との関係も 明らかになっていることから、今後の発展が期待される(55)。

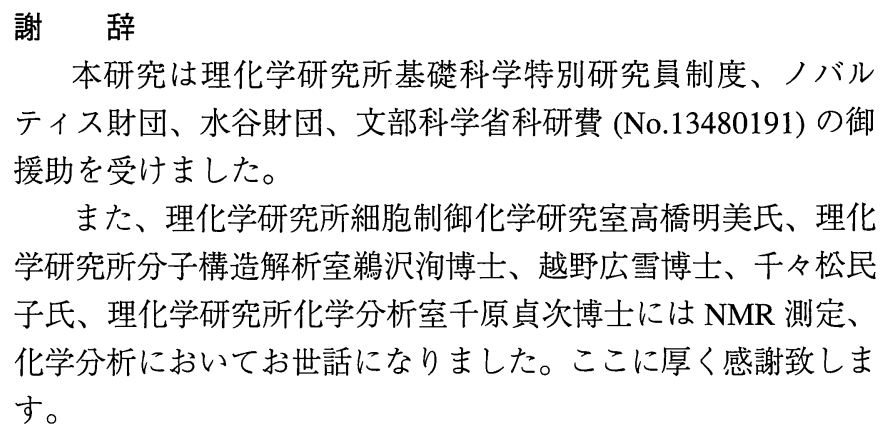

また、理化学研究所細胞制御化学研究室高橋明美氏、理化 学研究所分子構造解析室鵜沢洵博士、越野広雪博士、千々松民 子氏、理化学研究所化学分析室千原貞次博士には NMR 測定、 化学分析においてお世話になりました。ここに厚く感謝致しま す。

\section{References}

1. "The Cell" 4th edition, Eds B. Alberts A. Johnson, J. Lewis, M. Raff, K. Roberts, P. Walter. (2001) Garland science, NY

2. "Essentials of Glycobiology" A. Varki, A. Cummings, J. Esko, H. Freeze, G. Hart, J. Martin. (1999) Eds:Cold Spring Harbor Laboratory Press, Plainview, NY.

3. Dwek, R. A. (1996) Chem. Rev., 96, 683-720

4. Kobata, A. (1993) Acc. Chem. Res. 26, 319-324

5. Taylor, C. M. (1998) Tetrahedron 54, 11317-11362

6. Hofsteenge, J., Müller, D. R., de Beer, T., Löffler, A., Richter, W. J., Vliegenthart, J. F. G. (1994) Biochemistry 33, 13524-13530

7. de Beer, T., Vliegenthart, J. F. G., Löffler, A., Hofsteenge, J. (1995) Biochemistry 34, 11785-11789

8. Löffler, A., Doucey, M-A., Jansson, A. M., Müller, D. R., de Beer T., Hess D., Meldal, M., W. J. Richter, W. J., Vliegenthart, J. F. G., Hofsteenge, J. (1996) Biochemistry 35, 12005-12014

9. Vliegenthart, J. F. G., Casset, F. (1998) Curr. Opin. Struct. Biol. 8, 565-571

10. Hofsteenge, J., Löffler, A., Müller, D. R., Richter, W. J., de Beer, T. Vliegenthart, J. F. G. (1996) in Techniques in Protein Chemistry VII, D. R. Marshak ed. 163-171, Academic Press, New York

11. Doucey, M-A., Hess, D., Blommers, M. J. J., Hofsteenge, J. (1999) Glycobiology 9, 435-441

12. Hofsteenge, J., Huwiler, K. G., Macek, B., Hess, D., Lawler, J., Mosher, D. F., Peter-Katalinic, J. (2001) J. Biol. Chem. 276, 6485-6498

13. Gonzalez, P. A., Klein, D., Macek, B., Hess, D., Peter-Katalinic, J., Hofsteenge, J. (2002) Mol. Cell. Proteomics 1, 11-18

14. Hofsteenge, J., Blommers, M., Hess, D., Furmanek, A., Miroshnichenko, O. (1999) J. Biol. Chem. 274, 32786-32794

15. Hartmann, S., Hofsteenge, J. (2000) J. Biol. Chem. 275, 28569-28574

16. Fujise, H., Horiuchi, K., Adachi, K., Sano, H., Suzuki, K., Patent, WO99/09411. (Chem. Abstr. 1999, 130)

17. Garcia, A., Lenis, L. A., Jiménez, C., Debitus, C., Quiñoá, E., Riguera, R. (2000) Org. Lett. 2, 2765-2767

18. Hartmann, S., Hofsteenge, J. (2000) J. Biol. Chem. 275, 28569-28574

19. Krieg, J., Hartmann, S., Vicentini, A., Gläsner, W., Hess, D., Hofsteenge, J. (1998) Mol. Biol. Cell. 9, 301-309

20. Doucey, M-A., Hess, D., Cacan, R., Hofsteenge, J. (1998) Mol. Biol. Cell. 9, 291-300

21. Seitz, O. (2000) Chem Bio Chem 100, 4495-4537

22. Herzner, H., Reipen, T., Schltz, M., Kunz, H. (2000) Chem. Rev. 100, 4495-4537

23. Davis, B. G. (2002) Chem. Rev. 102, 579-601

24. Manabe, S., Ito, Y. (1999) J. Am. Chem. Soc. 121, 9754-9755

25. Manabe, S., Marui, Y., Ito, Y. (2003) Chem. Eur. J. 9, 1435-1446

26. Nishikawa, T., Ishikawa, M., Isobe, M. (1999) Synlett 123-125

27. Nishikawa, T., Ishikawa, M., Wada, K., Isobe, M. (2001) Synlett 945-947

28. Du, Y., Kong, F. (1995) J. Carbohydr. Chem. 14, 341-352

29. Bellosta, V., S. Czernecki, S. (1989) J. Chem. Soc., Chem. Commun. 199-200

30. Sundberg, R. J., Russell, H. F., (1973) J. Org. Chem. 38, 3324-3330

31. Manabe, S., Ito, Y., Ogawa, T. (1998) Chem. Lett. 919-920

32. Sato, K., Kozikowski, A. P. (1989) Tetrahedron Lett. 30, 4073-4076

33. Bennani, Y. L., Zhu, G-D, Freeman, J. C. (1998) Synlett 754-756

34. Schöllkopf, U., Groth, U., Deng, C. (1981) Angew. Chem. Int. Ed. Engl. 20, 798-799

35. Dellaria, Jr, J. F., Santarsiero, B. D., (1988) Tetrahedron Lett. 29, 6079-6082

36. Williams, R. M., Im, M-N. (1991) J. Am. Chem. Soc. 113, 9276-9286 
37. Bull, S. D., Davis, S. G., Epstein, S. W., Ouzman, J. V. A. (1998) Chem. Commun. 659-660

38. Vasella, A., Witzig, C., Chiara, J. L., Martin-Lomas, M. (1991) Helv. Chem. Acta 74, 2073-2077

39. Corey, E. J., Raju, N. (1983) Tetrahedron Lett. 25, 5571-5574

40. Epp, J. B., Widlanski, T. S. (1999) J. Org. Chem. 64, 293-294

41. Meldal, M., Juliano, M. A., Jansson, A. M. (1997) Tetrahedron Lett. 38, 2531-2534

42. Carpino, L. A., El-Faham, A. (1995) J. Am. Chem. Soc. 117, 5401-5402

43. Falchi, A., Giacomelli, G., Porcheddu, A., Taddei, M. (2000) Synlett 275-277

44. Kunishima, M., Kawachi, C., Hioki, K., Terao, K., Tani, S. (2001) Tetrahedron 57, 1551-1558

45. Isobe, M., Nishizawa, R., Hosokawa, S., Nishikawa, T. (1998) Chem. Commun. 2665-2676

46. Sonogashira, K., Tohda, Y., Hagihara, N. (1975) Tetrahedron Lett. 4467-4470

47. Castro, C. E., Gaughan, E. J., Owley, D. C. (1965) J. Org. Chem. 31, 587-592

48. Nishikawa, T., Kajii, S., Wada, K., Ishikawa, M., Isobe, M. (2002) Synthesis, 1658-1662

49. Nishikawa, T., Wada, K., Isobe, M. (2002) Biosci. Biotechnol. Biochem. 66, 2273-2278

50. Dunn, N. J., Jackson, R. F. W., Pietruszka, J., Wishart, N., Ellis, D., Wythes, M. J. (1995) J. Org. Chem. 60, 2210-2215

51. Larock, R. C., Yum, E. K. (1991) J. Am. Chem. Soc. 113, 6689-6690

52. Larock, R. C., Yum, E. K., Refvik, M. D. (1998) J. Org. Chem. 63, 7652-7662

53. Larock, R. C. (1999) J. Organomet. Chem. 576, 111-124

54. http://www.glycosuite.com/

55. Furmanek, A., Hofsteenge, J. (2000) Acta Biochimica Polonica 47, 781-789

Received on June 11, 2003, accepted on June 25, 2003

\section{Profile of the Authors}

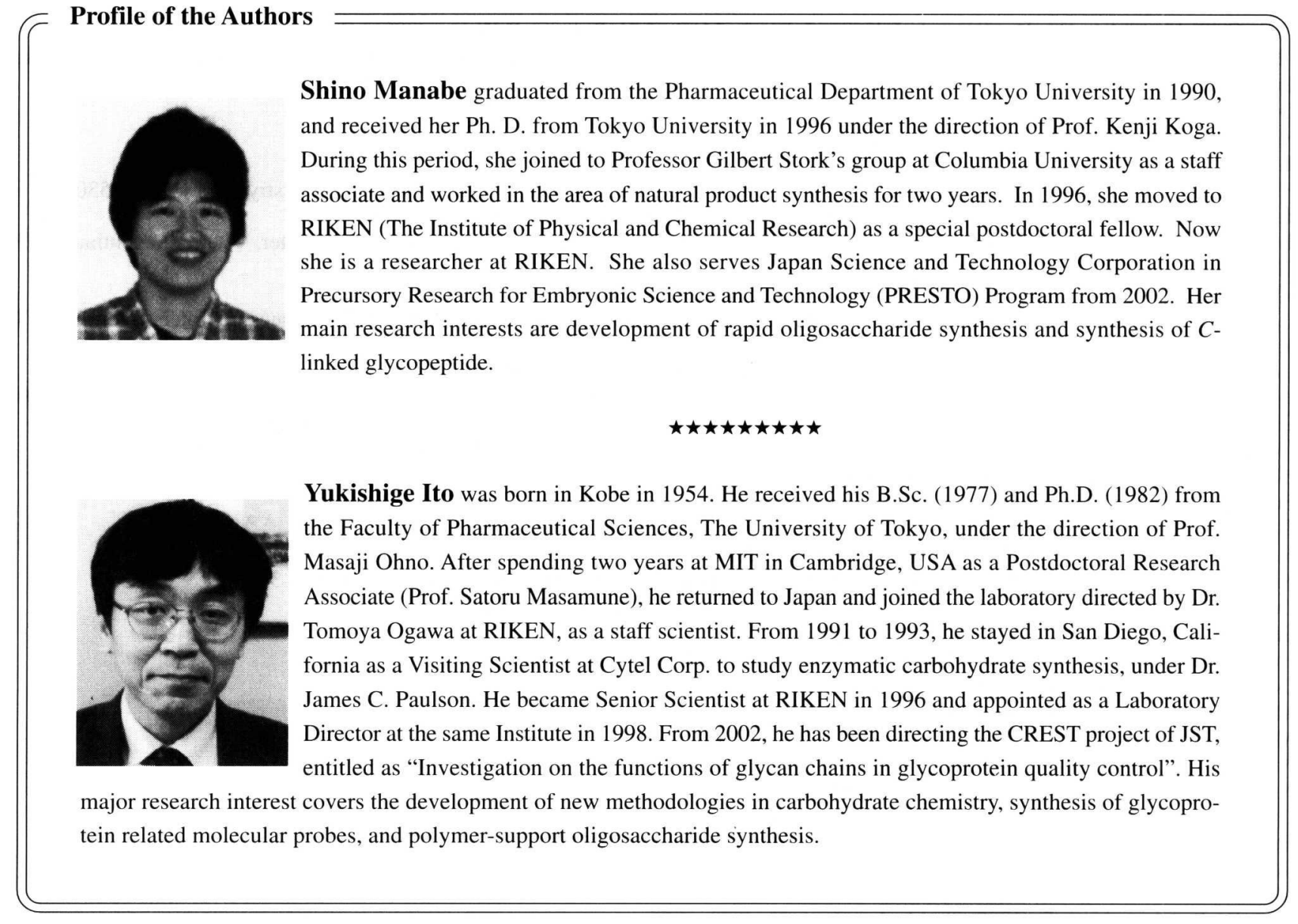

